\title{
Dicyclopentamethylenethiuram Disulfide as Precursor of Mononuclear Complexes: Oxidative Cleavage of Metal-Metal Bond in $\left[\mathrm{CpMo}(\mathrm{CO})_{3}\right]_{2}$ and Molecular Structure of cis-[CpMo(CO) $\left.{ }_{2}\left\{\mathrm{~S}_{2} \mathrm{C}-\mathrm{N}\left(\mathrm{CH}_{2}\right)_{5}\right\}\right]$
}

\author{
Md. Manzurul Karim1*, Shafikul Islam², Md. Rafikul Islam³, Mohammad R. Karim*, \\ Tasneem A. Siddiquee 4 \\ ${ }^{1}$ Department of Chemistry, Jahangirnagar University, Savar, Bangladesh \\ ${ }^{2}$ Department of Chemistry, Morning Glory School and College, Savar, Bangladesh \\ ${ }^{3}$ Department of Chemistry, Barisal Cadet College, Barisal, Bangladesh \\ ${ }^{4}$ Department of Chemistry, Tennessee State University, Nashville, TN, USA \\ Email: ^karim_ju1958@yahoo.com, chem.shafik@gmail.com, rafikchemju@gmail.com, *mkarim@tnstate.edu
}

How to cite this paper: Karim, M.M., Islam, S., Rafikul, I.M., Karim, M.R. and Siddiquee, T.A. (2017) Dicyclopentamethylenethiuram Disulfide as Precursor of Mononuclear Complexes: Oxidative Cleavage of Metal-Metal Bond in $\left[\mathrm{CpMo}(\mathrm{CO})_{3}\right]_{2}$ and Molecular Structure of cis- $\left[\mathrm{CpMo}(\mathrm{CO})_{2}\left\{\mathrm{~S}_{2} \mathrm{C}\right.\right.$ $\left.\left.\mathrm{N}\left(\mathrm{CH}_{2}\right)_{5}\right\}\right]$. Crystal Structure Theory and Applications, 6, 67-72.

https://doi.org/10.4236/csta.2017.64006

Received: October 18, 2017

Accepted: November 27, 2017

Published: November 30, 2017

Copyright @ 2017 by authors and Scientific Research Publishing Inc. This work is licensed under the Creative Commons Attribution International License (CC BY 4.0).

http://creativecommons.org/licenses/by/4.0/

\section{(c) (i) Open Access}

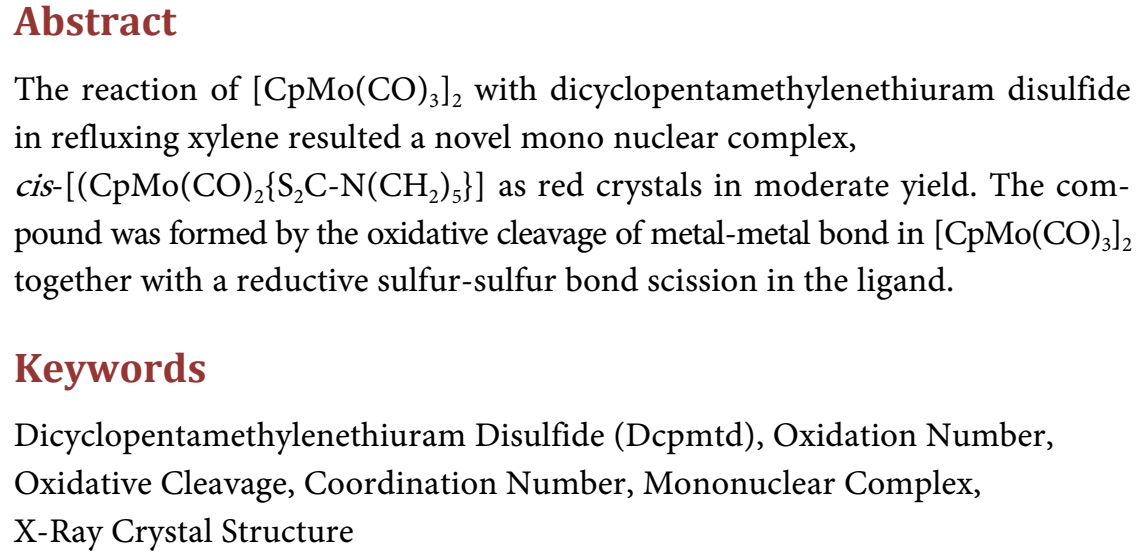

Abstract

The reaction of $\left[\mathrm{CpMo}(\mathrm{CO})_{3}\right]_{2}$ with dicyclopentamethylenethiuram disulfide in refluxing xylene resulted a novel mono nuclear complex, cis- $\left[\left(\mathrm{CpMo}(\mathrm{CO})_{2}\left\{\mathrm{~S}_{2} \mathrm{C}-\mathrm{N}\left(\mathrm{CH}_{2}\right)_{5}\right\}\right]\right.$ as red crystals in moderate yield. The compound was formed by the oxidative cleavage of metal-metal bond in $\left[\mathrm{CpMo}(\mathrm{CO})_{3}\right]_{2}$ together with a reductive sulfur-sulfur bond scission in the ligand.

\section{Keywords}

Dicyclopentamethylenethiuram Disulfide (Dcpmtd), Oxidation Number, Oxidative Cleavage, Coordination Number, Mononuclear Complex, X-Ray Crystal Structure

\section{Introduction}

Dithiocarbamate ligands are versatile ligands with applications in industry [1], agriculture [2] and biology [3]. Since these ligands contain nitrogen and sulfur donor atoms, they are capable of forming complexes with most of the elements [4]. A number of dithiocarbamate complexes have been reported in literature [5]-[12] with various geometries such as square planar [13], octahedral [14] [15] and trigonal prismatic [16]. Interestingly, their pyridine [6] [7] [17], 2,2'-bipyridine [7] 
[9] triphenylphosphine [18], and 1,10-phenanthroline [9] [17] adducts have been reported to possess similar donor properties. These ligands may stabilize monatomic metal ions in various oxidation states because of its chelating capacity thus forming mononuclear complexes [19]-[28]. The anionic form of N,N-dialkyl-1, 1-dithio-ligands is stable and the stability stems from the resonance of the anionic form of the ligand (Figure 1) [19].

Shi et al. reported the reaction between $\left[\mathrm{CpMo}(\mathrm{CO})_{2}\right]_{2}$ with tetramethylthiuram disulfide which yielded the mononuclear cyclopentadienyl molybdenum dithiocarbamate complex cis- $\left[\left(\mathrm{CpMo}(\mathrm{CO})_{2}\left\{\mathrm{~S}_{2} \mathrm{C}-\mathrm{N}\left(\mathrm{CH}_{3}\right)_{2}\right\}\right]\right.$ [29]. The compound is formed by oxidative cleavage of Mo-Mo triple bond together with a reductive S-S bond scission in tetramethylthiuram disulfide ligand (Scheme 1).

\section{Results}

We carried out the analogous reaction of dicyclopentamethylenethiuram disulfide with $\left[\mathrm{CpMo}(\mathrm{CO})_{3}\right]_{2}$ and reported herein the formation of a mononuclear cyclopentadienyl molybdenum dicarbonyl complex, cis- $\left[\left(\mathrm{CpMo}(\mathrm{CO})_{2}\left\{\mathrm{~S}_{2} \mathrm{C}-\mathrm{N}\left(\mathrm{CH}_{2}\right)_{5}\right\}\right]\right.$.

Treatment of $\left[\mathrm{CpMo}(\mathrm{CO})_{3}\right]_{2}$ with dicyclopentamethylenethiuram disulfide in refluxing xylene gave thermally stable complex cis- $\left[\left(\mathrm{CpMo}(\mathrm{CO})_{2}\left\{\mathrm{~S}_{2} \mathrm{C}-\mathrm{N}\left(\mathrm{CH}_{2}\right)_{5}\right\}\right]\right.$ as major reaction product (Scheme 2) which has been characterized by elemental analysis and spectroscopic methods [30]. The structure of the complex has been determined by single crystal X-ray diffraction [31] which is summarized in Figure 2.

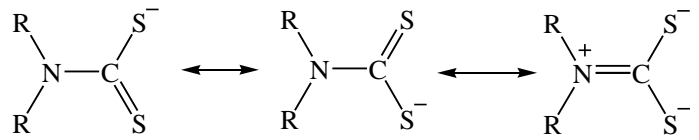

Figure 1. Resonance structures of anioic N,N-dialkyl-1,1-dithio ligand.

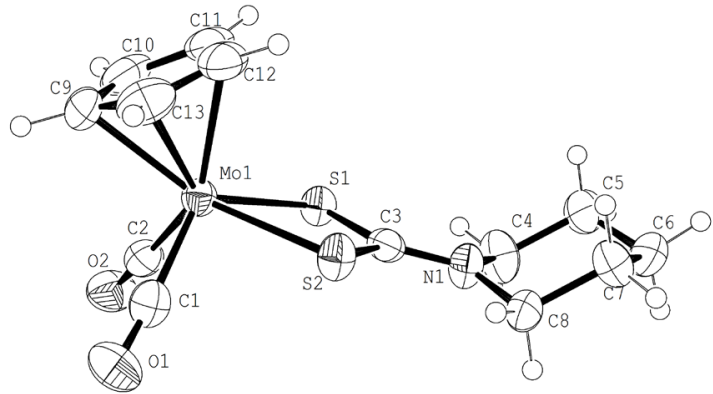

Figure 2. Molecular structure of cis- $\left[\left(\mathrm{CpMo}(\mathrm{CO})_{2}\left\{\mathrm{~S}_{2} \mathrm{C}-\mathrm{N}\left(\mathrm{CH}_{2}\right)_{5}\right\}\right]\right.$.

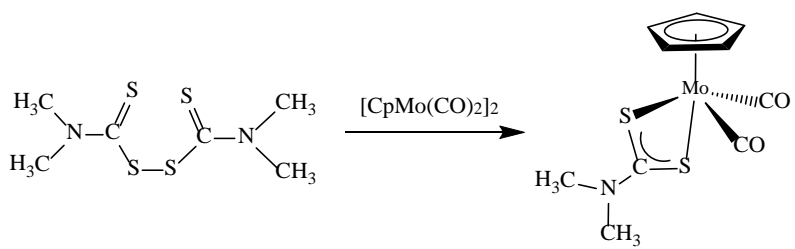

Scheme 1. Oxidative cleavage of Mo-Mo triple bond in thiuram disulfide by $\left[\mathrm{CpMo}(\mathrm{CO})_{2}\right]_{2}$ 


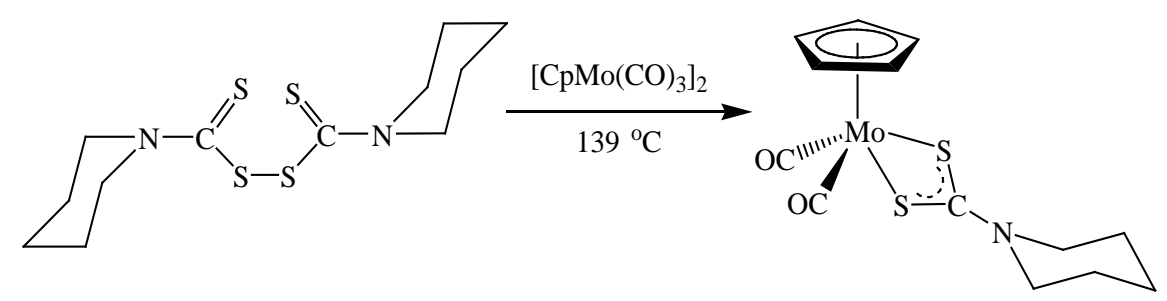

Scheme 2. Synthesis of cis- $\left[\left(\mathrm{CpMo}(\mathrm{CO})_{2}\left\{\mathrm{~S}_{2} \mathrm{C}-\mathrm{N}\left(\mathrm{CH}_{2}\right)_{5}\right\}\right]\right.$.

The molecular structure of cis- $\left[\left(\mathrm{CpMo}(\mathrm{CO})_{2}\left\{\mathrm{~S}_{2} \mathrm{C}-\mathrm{N}\left(\mathrm{CH}_{2}\right)_{5}\right\}\right]\right.$ shows a four-legged piano-stool configuration at $\mathrm{Mo}(\mathrm{II})$, being coordinated to a bidentate cyclo pentamethylene dithiocarbamate and two $\mathrm{CO}$ ligands, similar to the coordination found in the analogous complex ion cis- $\left[\left(\mathrm{CpMo}(\mathrm{CO})_{2}\left\{\mathrm{~S}_{2} \mathrm{C}-\mathrm{N}\left(\mathrm{CH}_{3}\right)_{2}\right\}\right]\right.$ (Scheme 2) [29]. Bond lengths $S(1)-C(3)$ and $S(2)-C(3)$ have been found 1.708(5) $\AA$, which is consistent with the partial C-S double bond [32]. The average Mo- $\mathrm{C}(\mathrm{Cp})$ bond distance in $c i s-\left[\left(\mathrm{CpMo}(\mathrm{CO})_{2}\left\{\mathrm{~S}_{2} \mathrm{C}-\mathrm{N}\left(\mathrm{CH}_{2}\right)_{5}\right\}\right]\right.$ has been found to be $2.326 \AA$, which is similar to the Mo-C $(\mathrm{Cp})$ average bond distance of $2.325 \AA$ as found in cis-[(CpMo $\left.(\mathrm{CO})_{2}\left\{\mathrm{~S}_{2} \mathrm{C}-\mathrm{N}\left(\mathrm{CH}_{3}\right)_{2}\right\}\right][29]$. Mo-S bond distance in cis- $\left[\left(\mathrm{CpMo}(\mathrm{CO})_{2}\left\{\mathrm{~S}_{2} \mathrm{C}-\mathrm{N}\left(\mathrm{CH}_{2}\right)_{5}\right\}\right]\right.$ was found $2.500 \AA$ which is similar to the average Mo-S bond distance reported in cis- $\left[\left(\mathrm{CpMo}(\mathrm{CO})_{2}\left\{\mathrm{~S}_{2} \mathrm{C}-\mathrm{N}\left(\mathrm{CH}_{3}\right)_{2}\right\}\right](2.503 \AA)\right.$ [29]. Average Mo-CO bond distance in cis- $\left[\left(\mathrm{CpMo}(\mathrm{CO})_{2}\left\{\mathrm{~S}_{2} \mathrm{C}-\mathrm{N}\left(\mathrm{CH}_{2}\right)_{5}\right\}\right]\right.$ is $1.962 \AA$. Similar average Mo-CO bond distance $1.958 \AA$ was found in cis-[(CpMo $\left.(\mathrm{CO})_{2}\left\{\mathrm{~S}_{2} \mathrm{C}-\mathrm{N}\left(\mathrm{CH}_{3}\right)_{2}\right\}\right]$ (Figure 2) [29].

Selected bond lengths $[\AA]$ and bond angles $\left[{ }^{\circ}\right]: \mathrm{Mo}(1)-\mathrm{C}(1)$ 1.958(6), $\mathrm{Mo}(1)-\mathrm{C}(2)$ 1.966(6), $\mathrm{Mo}(1)-\mathrm{C}(9)$ 2.275(6), $\mathrm{Mo}(1)-\mathrm{C}(10)$ 2.300(6), $\mathrm{Mo}(1)-\mathrm{C}(13)$ 2.306(6), $\mathrm{Mo}(1)-\mathrm{C}(12)$ 2.363(6), $\mathrm{Mo}(1)-\mathrm{C}(11)$ 2.384(6), $\mathrm{Mo}(1)-\mathrm{S}(1)$ 2.505(2), Mo(1)-S(2) 2.495(3), S(1)-C(3) 1.708(5), S(2)-C(3) 1.708(5), C(2)-Mo(1)-C(1) 5.7(2), C(2)-Mo(1)-S(1) 81.47(19), C(1)-Mo(1)-S(1) 121.98(18), S(2)-Mo(1)-S(1) 68.55(7).

The complex, cis- $\left[\left(\mathrm{CpMo}(\mathrm{CO})_{2}\left\{\mathrm{~S}_{2} \mathrm{C}-\mathrm{N}\left(\mathrm{CH}_{2}\right)_{5}\right\}\right]\right.$ was obtained by the oxidative cleavage of the Mo-Mo bond in $\left[\mathrm{CpMo}(\mathrm{CO})_{3}\right]_{2}$ which is consistent with the increase in oxidation number of Mo atom in the complex from +1 to +2 . The geometry of the compound can be described as square-pyramidal with $\mathrm{Cp}-\mathrm{Mo}$ defining the vertex and $C(1), C(2), S(1)$ and $S(2)$ atoms defining the base. The base of this complex is not a regular square because of unequal bond lengths of Mo-S and Mo-C bonds. In complex cis- $\left[\left(\mathrm{CpMo}(\mathrm{CO})_{2}\left\{\mathrm{~S}_{2} \mathrm{C}-\mathrm{N}\left(\mathrm{CH}_{2}\right)_{5}\right\}\right]\right.$, the cyclopentadienyl ligand acts as five electron donor and dithiocarbamate acts as three electron donor ligand. The complex is thermally stable and follows 18-electron rule.

\section{Acknowledgements}

The authors acknowledge ministry of science and technology, Bangladesh for financial assistance and Department of chemistry, Jahangirnagar University for providing the laboratory facility. 


\section{References}

[1] Amdio, E., Cavinato, G., Domella, A., Ronchini, L., Toniolo, L. and Vavasori, A. (2009) New Carboalkoxybis(Triphenylphosphine)Palladium(II) Cationic Complexes: Synthesis, Characterization, Reactivity and Role in the Catalytic Hydrocarboalkoxylation of Ethene. X-Ray Structure of Trans-[Pd(COOMe)(TsO)(PPh3)2]-2CHCl3. Journal of Molecular Catalysis A: Chemical, 298,103. https://doi.org/10.1016/j.molcata.2008.10.002

[2] European Food Safety Authority (EFSA) (2011) The European Union Report on Pesticide Residues. EFSA, 9, 2430.

[3] Rehman, M., Hussain, A., Rehman, Z., Rauf, F.A., Hassan, A., Tahir, A. and Ali, S. (2010) New Tetrahedral, Square-Pyramidal, Trigonal-Bipyramidal and Octahedral Organotin(IV) 4-Ethoxycarbonylpiperazine-1-Carbodithioates: Synthesis, Structural Properties and Biological Applications. Journal of Organometallic Chemistry, 695, 1526. https://doi.org/10.1016/j.jorganchem.2010.03.008

[4] Brown Jr., T.L., Lemayand, E.H. and Bursten, B.E. (2000) Chemistry: The Central Science. 8th Edition, Prentice Hall International, Washington.

[5] Doadrio, A.L., Sotelo, J. and Fern'andez-Ruano, A. (2002) Synthesis and Characterization of Oxovanadium(IV) Dithiocarbamates with Pyridine. Quimica Nova, 25, 525. https://doi.org/10.1590/S0100-40422002000400002

[6] Sharma, M. and Sachar, R. (2009) Synthesis and Characterization of the Adducts of bis(N,N-Diethyldithiocarbamato)Oxovanadium(IV) with Substituted Pyridines. Oriental Journal of Chemistry, 25, 215.

[7] Manohar, A., Ramalingam, K., Bocelli, G. and Cantoni, A. (2010) Synthesis, Spectral and Single Crystal X-Ray Structural Studies on bis(2,2'-bipyridine)Sulphidom(II) (M $=\mathrm{Cu}$ or $\mathrm{Zn}$ ) and Diaqua 2,2'-Bipyridine Zinc(II)Sulphatedihydrate. Journal of the Serbian Chemical Society, 75, 1085. https://doi.org/10.2298/JSC091019097M

[8] Ekennia, A.C. (2013) Antibacterial Application of Novel Mixed-Ligand Dithiocarbamate Complexes of Nickel (II). Journal of Applied Chemistry, 5, 36.

[9] Geetha, N. and Thirumaran, S. (2008) Characterization Studies and Cyclic Voltammetry on Nickel(II) Amino Acid Dithiocarbamates with Triphenylphosphine in the Coordination Sphere. Journal of the Serbian Chemical Society, 73, 169. https://doi.org/10.2298/JSC0802169G

[10] Sovilj, S.P., Vuckovic, G., Leovac, M. and Minic, D. (2000) Dinuclear Copper(II) Complexes of N,N',N",N"'-tetrakis(2-pyridylmethyl)-1,4,8,11-tetraazacyclotetradecane and Some N,S or N,O Bidentate Ligands. Polish Journal of Chemistry, 74, 945.

[11] Sharma, M., Sharma, A. and Sachar, R. (2013) Preparation and Characterization of the Adducts of bis(N,N-diethyldithiocarbamato)oxovanadium(IV) and copper(II) with n-propylamine and Isopropylamine. Chemical Science Transactions, 2, 367. https://doi.org/10.7598/cst2013.265

[12] Sharma, M., Sharma, A. and Sachar, R. (2012) Synthesis and Characterization of the Adducts of Morpholinedithioccarbamate Complexes of Oxovanadium(IV), Nickel(II) and Copper(II) with Piperidine and Morpholine. Journal of Chemistry, 9, 1929. https://doi.org/10.1155/2012/689501

[13] Onwudiwe, D.C. and Ajibade, P.A. (2011) Synthesis, Characterization and Thermal Studies of $\mathrm{Zn}(\mathrm{II}), \mathrm{Cd}(\mathrm{II})$ and $\mathrm{Hg}(\mathrm{II})$ Complexes of N-methyl-N-phenyl Dithiocarbamate: The Single Crystal Structure of $[(\mathrm{C}(6) \mathrm{H}(5))(\mathrm{CH}(3)) \mathrm{NCS}(2)](4) \mathrm{Hg}(2)$. International Journal of Molecular Sciences, 12, 1964. https://doi.org/10.3390/ijms12031964 
[14] Osowole, A.A., Kolawole, G.A. and Fagade, O.E. (2005) Synthesis, Physicochemical, and Biological Properties of Nickel(II), Copper(II), and Zinc(II) Complexes of an Unsymmetrical Tetradentate Schiff Base and Their Adducts. Synthesis and Reactivity in Inorganic, Metal-Organic and Nano-Metal Chemistry, 35, 829. https://doi.org/10.1080/15533170500358168

[15] Kolawole, G.A. and Osowole, A.A. (2009) Synthesis and Characterization of Some metal(II) Complexes of Isomeric Unsymmetrical Schiff Bases and Their Adducts with Triphenylphosphine. Journal of Coordination Chemistry, 62, 1437. https://doi.org/10.1080/00958970802621512

[16] Guo, T., Lai, C.S., Tan, X.J., Teo, C.S. and Tiekink, E.R. (2002) Bis(diethyldithiocarbamato) (4,7-dimethyl-1,10-phenanthroline)cadmium(II) Acetonitrile Solvate. Acta Crystallographica-Section E: Structure Reports Online, 58, 439. https://doi.org/10.1107/S1600536802012679

[17] Shashi, B.K., Geetanjli, K. and Priyanka (2011) Synthesis and Characterization of Pyridine Adducts of Some Transition Metal 4-Methylpiperazine-1-Carbodithioic Acid Complexes. Himachal Pradesh University Journal, 1.

[18] Mamba, S.M. (2011) Synthesis, Characterization and Application of Dithiocarbamate Transition Metal Complexes. PhD Thesis, University of Johannesburg, Johannesburg.

[19] Karlin, K.D. (2005) Progress in Inorganic Chemistry. John Wiley and Sons, Inc., 53, 71.

[20] Deeming, A.J., Forth, C. and Hogarth, G. (2007) Synthesis and Crystal Structure of [Ru8 $(\mu 5-S) 2(\mu 4-S)(\mu 3-S)(\mu-C N M e 2) 2(\mu-C O)(C O) 15]$ Formed via the Double Sulphur-Carbon Bond Cleavage of dithiocarbamate ligands. Journal of Organometallic Chemistry, 692, 4000. https://doi.org/10.1016/j.jorganchem.2007.05.044

[21] Karim, M.M., Abser, M.N., Hassan, M.R., Ghosh, N., Alt, H.G., Richards, I. and Hogarth, G. (2012) Oxidative-Addition of Thiuram Disulfides to Osmium(0): Synthesis of cis-[Os(CO)2(S2CNR2)2] (R = Me, Et, Cy, CH2CH2OMe) and Molecular Structures of cis-[Os(CO)2(S2CNMe2)2] and $[(\mathrm{MeOCH} 2 \mathrm{CH} 2) 2 \mathrm{NCS}] 2$. Polyhedron, 42, 84. https://doi.org/10.1016/j.poly.2012.04.042

[22] Ziegler, M.L., Weber, H., Nuber, B. and Serhadle, O. (1987) Synthesis and Characterization of the Zwitterion S2CC(NMe2)2, a Transition Metal Induced Carbon-Carbon Coupling. Complex Chemistry of the Zwitterions S2CC(NR2)2. Zeitschrift für Naturforschung, 42b, 141.

[23] Catheline, D., Roman, E. and Astruc, D. (1984) Reactivity of the Monodentdithiocarbamate Ligand in $\mathrm{CpFe}(\mathrm{CO}) 2(\eta 1-\mathrm{S} 2 \mathrm{CNR} 2)$. Inorganic Chemistry, 23, 4508. https://doi.org/10.1021/ic00194a021

[24] Maheu, L.J., Miessler, G.L., Berry, J., Burow, M. and Pignolet, L.H. (1983) Di- and Tri-thiocarbamato Complexes of Osmium(III) and the Crystal and Molecular Structure of [Os2(SeS2CNMe2)2(S2CNMe2)3]PF6. Inorganic Chemistry, 22, 405. https://doi.org/10.1021/ic00145a009

[25] Hope, J.M., Martin, R.L., Taylor, D. and White, A.H. (1977) Ring Expansion in a Metal-Dithiocarbamate Complex by Oxygen Insertion; Synthesis and Properties of [Cr(S2CNR2)2(OS2CNR2)]. The X-Ray Structure of bis[NN-diethyl (dithiocarbamato-SS')][NN-diethyl(dithioperoxycarbamato-OS)]chromium(III). Journal of the Chemical Society, Chemical Communications, 99. https://doi.org/10.1039/C39770000099

[26] Martin, R.L., Patrick, J.M., Skelton, B.W., Taylor, D. and White, A.H. (1982) Crystal Structure of bis[N,N-diethyl(dithiocarbamato-S,S')]-[N,N-diethyl (dithioperoxycarbamato-O,S)]chromium(III). A Redetermination. Australian Journal of Chemi- 
stry, 35, 2551. https://doi.org/10.1071/CH9822551

[27] Fackler, J.P. and Holah, D.G. (1966) Sulfur Chelates. II. Five-Coordinate Transition Metal Complexes. Inorganic and Nuclear Chemistry Letters, 2, 251. https://doi.org/10.1016/0020-1650(66)80055-7

[28] Pignolet, L.H., Lewis, R.A. and Holm, R.H. (1971) Synthesis and Stereochemical Rearrangements of Complexes Containing the Fe-S6 Core. Journal of the American Chemical Society, 93, 360. https://doi.org/10.1021/ja00731a011

[29] Shi, Y., Cheng, G., Lu, S., Guo, H., Wu, Q., Huang, X. and Hu, N. (1993) The Cleavage Reaction of the Molybdenum-Molybdenum Triple Bond. The Crystal Structures of Molybdenum Complexes [CpMo(CO)2(C5H4NS)], [CpMo(CO)2 (C9H6NS)]O:PPh3 and [CpMo(CO)2(S2CNMe2)]. Journal of Organometallic Chemistry, 455, 115. https://doi.org/10.1016/0022-328X(93)80389-S

[30] To a xylene $(40 \mathrm{~mL})$ of $\left[\mathrm{CpMo}(\mathrm{CO})_{3}\right]_{2}(0.200 \mathrm{~g}, 0.408 \mathrm{mmol})$ Was Added Dicyclopentamethylenethiuram Disulfide $(0.196 \mathrm{~g}, 0.612 \mathrm{mmol})$ and the Reaction Mixture Was Refluxed for 1 Hour. The Color Was Changed from Red to Red Brown. The Solvent Was Removed under Reduced Pressure and Residue Chromatographed by TLC on Silica. Elution with Cyclohexane/Dichloromethane $(3: 2 \mathrm{~V} / \mathrm{V})$ Gave One Band cis- $\left[\left(\mathrm{CpMo}(\mathrm{CO})_{2}\left\{\mathrm{~S}_{2} \mathrm{C}-\mathrm{N}\left(\mathrm{CH}_{2}\right)_{5}\right\}\right](0.167 \mathrm{~g}, 36.16 \%)\right.$ as Red Brown Crystal from Dichloromethane/Hexane Mixture at $-4{ }^{\circ} \mathrm{C}$. Elemental Analysis: Found $\mathrm{C}=$ 41.36, $\mathrm{H}=3.99, \mathrm{~N}=3.70, \mathrm{~S}=16.94 \%$ and $\mathrm{C}_{13} \mathrm{H}_{15} \mathrm{MoNO}_{2} \mathrm{~S}_{2}$ Requires $\mathrm{C}=41.34, \mathrm{H}=$ 3.98, $\mathrm{N}=3.71, \mathrm{~S}=16.96 \%$. IR $\left(v_{\mathrm{CO}}\right)$ in $\mathrm{cm}^{-1}: 1857.53(\mathrm{~s}), 1949.15(\mathrm{~s}) .{ }^{1} \mathrm{H}$ NMR $(\mathrm{ppm})$ : $1.54(\mathrm{~m}, 3 \mathrm{H}), 1.63(\mathrm{~m}, 3 \mathrm{H}), 3.56(\mathrm{~m}, 2 \mathrm{H}), 3.79(\mathrm{~m}, 2 \mathrm{H}), 5.41(\mathrm{~s}, 5 \mathrm{H})$. FAB mass $(\mathrm{m} / \mathrm{z}): 377\left[\mathrm{M}^{+}\right], 349\left[\mathrm{M}^{+}-\mathrm{CO}\right], 321\left[\mathrm{M}^{+}-2 \mathrm{CO}\right], 257\left[\mathrm{M}^{+}-2 \mathrm{CO}-2 \mathrm{~S}\right]$, etc.

[31] Crystal Data for cis- $\left[\left(\mathrm{CpMo}(\mathrm{CO})_{2}\left\{\mathrm{~S}_{2} \mathrm{C}-\mathrm{N}\left(\mathrm{CH}_{2}\right)_{5}\right\}\right]\right.$ : Empirical Formula $\mathrm{C}_{13} \mathrm{H}_{15} \mathrm{MoNO}_{2} \mathrm{~S}_{2}$, $\mathrm{MW}=377.32$, Triclinic, Space groupP1, $\mathrm{a}=6.449(7) \AA \mathrm{A}, \mathrm{b}=10.634(10) \AA, \mathrm{c}=11.383(12)$ $\AA, \alpha=71.94(3)^{\circ}, \beta=82.31(3)^{\circ}, \gamma=76.43(3)^{\circ}, V=719.9(13) \AA^{3}, T=273(2) \mathrm{K}, Z=2$, $\mu=1.197 \mathrm{~mm}-1, \mathrm{~F}(000) 380$, density (calculated) $1.741 \mathrm{Mg} / \mathrm{m}^{3}, 7722$ Reflections Collected, 3303 Independentreflections $[\mathrm{R}(\mathrm{int})=0.0477]$. The Final $\mathrm{R} 1=0.0486, \mathrm{wR} 2=$ $0.1288[\mathrm{I}>2 \sigma(\mathrm{I})], \mathrm{R}$ Indices (all data) $\mathrm{R} 1=0.0719, \mathrm{wR} 2=0.1566$.

[32] Lide, D.R. (2003-2004) Handbook of Chemistry and Physics. 84th Edition, CRC Press, Sec. 9, 10.

\section{Supplementary Material}

Crystallographic data for cis- $\left[\left(\mathrm{CpMo}(\mathrm{CO})_{2}\left\{\mathrm{~S}_{2} \mathrm{C}-\mathrm{N}\left(\mathrm{CH}_{2}\right)_{5}\right\}\right]\right.$ has been deposited at the Cambridge Crystallographic Centre with CCDC Reference Number CCDC 1567351. Copy of the data can be obtained free of charge via https://www.ccdc.cam.ac.uk/conts/retrieving.html (or from Cambridge Crystallographic Data Centre, 12 Union Road, Cambridge CB2 1EZ, UK (Tel: +441223 336408; fax: +44 1223 336033; email: deposit@ccdc.cam.ac.uk)). 